\section{Soviet academies}

\section{Coordination and management}

THE Praesidium of the Academy of Sciences of the USSR is housed in the former mansion (now overrun by central Moscow) of a rich iron and steel family, with a handsome cast-iron staircase to advertise the family's wares. Three hundred metres away is a new white skyscraper (tall by Moscow's alluvial standards), with gilt moulding in a thick band around the top. The academy would have moved to the latter by now had the government not decreed that work on expensive buildings should be suspended.

Is the hiatus symbolic, perhaps of the uncertainty in knowing how perestroika will touch the most august of scientific institutions in the Soviet Union? Time, no doubt, will tell. Meanwhile, the academy has embarked on a modest programme of internally directed change.

That the Soviet academy is much more than a means by which distinguished scholars elect others of their kind to join them has its roots in the foundation of its predecessor, the St Petersburg Academy, by Peter the Great. His model was the Berlin academy of the eighteenth century. The academy has been an agent of research from the outset.

Now, with more than 250 research institutes and 200,000 research scientists on its payroll, the academy is not merely the agent of much of the Soviet Union's research effort but, because of its prestige as an institution and the personal influence of its members, has a dominating influence on the whole pattern of Soviet science and higher education. It is no wonder that the 250 academicians are widely respected and recognized as powerful people (but some academicians eschew the second attribute.) In social status, academicians compare with government ministers (of whom there are a great many in the Soviet Union.)

The growth of the academy's influence began with its move from Leningrad to Moscow in 1933, and rests to a large degree on the contribution of many academicians to meeting nationally important goals, the defence of the Soviet Union in particular.

More recently, academicians have played decisive parts in tackling national emergencies (vice-president Velikhov's role after Chernobyl), in shaping the pattern of industry (vice-president Ovchinnokov's influence on the development of biotechnology) and in developing a pacific space programme (as mounted by R.Z.Sagdeev's Space Research Institute).

Now, of course, there are other academies. Those for agricultural and medical sciences are national or "all-union" institutions modelled structurally on the academy of sciences. The fact that the academy was not able to halt Lysenko's influence on Soviet agriculture from his base at the academy of agricultural sciences may have seemed a black mark at the time, but his fall from power can only have helped the academy of sciences.

There are also academies of sciences for each of the fourteen republics of the union (apart from the Russian Republic), with a further 250 research institutes between them. For administrative purposes, the academy split off its Siberian activities into a separate division in 1958, and has created Far East and Urals divisions. Centres such as Leningrad, with a number of important research institutes, enjoy a degree of local autonomy similar to that of, say, the Far Eastern Branch.

Although these separate institutions all enjoy a degree of independence, their work is to a greater or lesser degree coordinated by what is generally called the "big academy", which also frequently takes the initiative in creating the committees coordinating other nationally important aspects of science.

This, for example, is the spirit in which the academy has this year taken the lead in safeguarding the Soviet government's interest in the development of ceramic superconductors. On the grounds that the first need is to understand the nature of the phenomenon, the academy has also broken new ground by inviting applications for research funds from all institutions considering themselves qualified to take a serious interest in the field, universities as well as public research institutes.

According to $\mathrm{Dr}$ Arnold Romanov, deputy chief scientific secretary (and a long-standing associate of Academician G.I. Marchuk, the newly-elected president), the new arrangement constitutes "an element of perestroika". It is too soon to tell, he says, whether this device for supporting research will be followed in other fields, but the State Committee on Science and Technology must first have a chance to give its opinion on the success of the scheme.

The management of the academy's interest in research is necessarily complicated. The academy is organized into 17 divisions, each of which is in the charge of an "academician-secretary" responsible for coordinating the work of relevant institutes and for organizing scientific committees reporting on special subjects. These, together with the vice-presidents of the academy and some 17 academicians without central executive responsibility, the president and the academician-secretary, constitute the praesidium of the academy, which meets once each week.

Individual academicians belong to one or other of the divisions, and in that role

\section{Acknowledgements}

This survey would not have been possible without some of the changes Mr Mikhail Gorbachev has already engineered. The recipe is glasnost, meaning "openness", the buzz-word until it was overtaken in the spring by perestroika, meaning "reconstruction". (The Russian word for "reform" could have been used instead if it had not been discredited by its use in the early days of the Brezhnev era, now known as the "period of stagnation.")

The writer (John Maddox, editor of Nature), was invited to the Soviet Union as a guest of the Academy of Sciences of the USSR (referred to as "the academy" in what follows) and enabled to see what he had asked to see (with the exception of the Physical-Technical Institute in Moscow, said to be in a region of the city which is out of bounds to foreigners, and an appointment with vice-president of the academy, Y. Velikhov, which did not materialize). At no point did an academy scientist obfuscate the answer to a question, which is not to say that there were no disputed answers; some administrators were more reticent. Hotel and travel costs within the Soviet Union were met by the academy; Nature will find some way of reciprocating.

No spell of three weeks can condense into 24 pages a measured account of science in the Soviet Union - and this account is deficient in concentrating on the Russian republic (to the exclusion of the other fourteen) and on one of the several agencies responsible for research in the Soviet Union, the Academy of Sciences of the USSR (which is nevertheless the most important).

The writer is particularly grateful to his guides for most of three weeks. They are Professor Maxim Frank-Kaminetskii of the Moscow Institute of Molecular Genetics, a theoretical physicist turned molecular biologist, whose several applications to accept invitations to speak at conferences abroad have been rejected (most recently this summer), and who is Jewish, and Dr Anvar Shukurov, from the largely Moslem republic of Tadjikistan (on the border with Afghanistan), a graduate of Moscow University, and now a member of the staff of the Space Research Institute at Moscow, whose chief interest is in astrophysical magnetic dynamos.

have been able to influence questions such as the appointment of people to fill important posts - directors of research institutes, for example.

The academy's relations with other organs of the Soviet government are also necessarily complicated. The academy is a creature of the Council of Ministers, essentially the executive branch of the government. The academy's work and future plans, like those of other academies, are grist for the mill of the State Committee on Science and Technology.

The academy is also the repository of a number of other important functions the negotiation of agreements on the exchange of people with its opposite numbers elsewhere, for example. This is the spirit in which an academy delegation will be visiting Britain early in November, and in which a US delegation will arrive in Moscow later the same month. 